I. I. Chudyk ${ }^{1}$, orcid.org/0000-0002-7402-6962,

Ya. M. Femiak ${ }^{1}$, orcid.org/0000-0003-4445-6731, M. I. Orynchak ${ }^{1}$, orcid.org/0000-0002-7523-830X,

A. K. Sudakov ${ }^{2}$, orcid.org/0000-0003-2881-2855, A. I. Riznychuk ${ }^{1}$, orcid.org/0000-0003-3149-8393
1 - Ivano-Frankivsk National Technical University of Oil and Gas, Ivano-Frankivsk, Ukraine, e-mail: chudoman@ukr.net 2 - Dnipro University of Technology, Dnipro, Ukraine

\title{
NEW METHODS FOR PREVENTING CRUMBLING AND COLLAPSE OF THE BOREHOLE WALLS
}

Purpose. To increase the stability of the wellbore during its construction in unstable rocks.

Methodology. To solve the set tasks, an integrated approach is used in the work, which includes critical analysis and generalization of scientific and technical achievements in combination with theoretical and experimental research.

Findings. Factors influencing the stability of the borehole walls in conditions prone to rock slides and rock falls are analyzed. Expediency of using baths for strengthening the walls of wells in deposits of clay rocks, including clay shales, has been established and substantiated. A formulation of a fuel-bituminous bath has been proposed, the installation of which in a well for 7-8 hours makes it possible to increase the initial compressive strength of rocks, which will ensure the integrity of the borehole walls. It is recommended to use corrugated casing pipes to cover the sections of the wellbore where there is intensive crumbling and collapse of rocks.

Originality. For the first time, the main factors of wall destruction have been established and a method has been developed to prevent the destruction of walls of directional wells composed of rocks prone to loss of stability under the action of drill string loads.

Practical value. To combat the collapse of the walls of the well composed of rocks, prone to loss of stability, the authors suggested setting up fuel-bituminous baths in the range of complications. In case when the collapse of the walls of the well can not be prevented with a fuel-bitumen bath, it is proposed to overlap the area of collapse with the casing using advanced corrugated casing pipes with the injection of adhesive into the rock mass in the near-wellbore zone. The use of an adhesive material increases the contact area of the metal shell with the rock, which collapses increasing the stability of the borehole walls.

Keywords: drilling, drilling fluids, bath, cavern, crumbling, collapse, corrugated casing

Introduction. The current state of oil and gas production in Ukraine is characterized by the depletion of the main reserves of hydrocarbons that are at the final stage of development, as well as by geographical location near urbanized territories and recreational areas. This circumstance, in combination with the most difficult mining and geological conditions in Europe, necessitates the construction of wells with a complex spatial architecture, in particular, directional and horizontal wells [1]. However, the drilling of such wells is associated with a number of problems $[2,3]$.

Formulation of the problem. The main problems that may arise in this case are associated with insufficient stability of the wellbore, which in most cases leads to a drill pipe sticking and a significant increase in material costs and production time for its elimination.

Intensive crumbling and collapse of the borehole walls usually occur in tectonically disturbed deposits of mudstones, siltstones, shales and small layers of sandstones. The primary cause of collapses and cave-ins of the borehole walls is the geological and technological conditions for the formation of the rock matrix, as well as the penetration of drilling fluid filtrate into the borehole walls to a considerable depth, which reduces the osmotic state of cohesion in the rock, as a result of which the size of cracks increases and the intensity of swelling of rocks increases. This, in turn, leads to a collapse of the walls of the well.

The density of drilling fluids, low mechanical and running speed of drilling, frequent stops and downtime for technical, technological and organizational reasons have a significant impact on the intensity of crumbling and collapse of the borehole walls. Collapses can cause accidents with the drilling tool (sticking of the drill string), especially in cavitation intervals.

(C) Chudyk I. I., Femiak Ya. M., Orynchak M.I., Sudakov A. K., Riznychuk A. I., 2021
The mechanism of caving formation is associated with soil expansion of clay minerals due to a decrease in lateral and osmotic pressure, as well as suction of filtrate from the drilling fluid. Penetrating into the cracks of clay rocks, the filtrate promotes an increase in capillary pressure in them, swelling and falling out of clay rocks due to interplanar hydration, a decrease in cohesion forces, which leads to cave-ins and collapses of the borehole walls. Swelling and slaking of clay rocks have a significant effect on the intensity of cave-ins and collapse of the borehole walls. In this case, the degree of cleavage of clay rocks is determined by the degree of hydration of clay particles and the rate of hydration of the clay mass, equal to the rate of water diffusion.

Hydration and wetting significantly change the stress state of rocks, in which there is an adsorptive decrease in hardness, the distribution area of which is very large and, over time, practically spreads over the entire volume of the rock sample. In this case, the adhesion forces between clay particles are screened, which leads to arbitrary dispersion without passing to the rock, or to significant deformations, provided that a load is applied.

Two mechanisms of swelling of clay minerals are known: crystalline and osmotic.

Crystalline swelling is also called surface hydration. It occurs as a result of the adsorption of monomolecular rocks of water on the basal outer and inner surfaces of crystals. The first layer of water is held on the surface by hydrogen bonds with oxygen atoms. That is, water molecules form a structure similar to that of a clay mineral and penetrate up to $1 \mathrm{~mm}$ from the outer surface. Such water has quasi-crystalline properties, the specific volume of which is $3 \%$ higher than the specific volume of free water, and it also has a high viscosity.

Osmotic swelling occurs due to the fact that the concentration between the layers of the crystal lattice is greater than 
their concentration in solution. Therefore, water is drawn into the interlayer space, as a result of which the formation of double spectral layers is possible. In clay minerals, no semipermeable membranes are observed, but the swelling has an osmotic character, which is associated with the difference in the concentration of the electrolyte.

Osmotic swelling compared to crystalline swelling leads to a significant increase in the total volume of the clay mineral. During osmotic swelling, sodium clays adsorb 20 times more water than during crystalline swelling.

The repulsive forces between the layers are much weaker during osmotic swelling compared to crystalline one. It is very difficult to counteract the destruction of the borehole walls when drilling out tectonically disturbed rocks.

Also, a dangerous complication during the process of drilling a well is the phenomenon of keyseating, which occurs due to one-sided deterioration of the borehole wall from rotation of the drill string, the action of vibrations and from trips during round trips in areas with an intensive change in the zenith angle. During the drilling phase, the presence of a keyseats can lead to overpull or slacking of drill pipes, and during the well completion phase, there is a threat of casing failure and poorquality cementing.

High standards of well construction require improvements in drilling tool designs and drilling technologies. Typically, the drilling tool operates in aggressive and abrasive environments under the influence of intense dynamic or long-term cyclic loads. In this direction, the issues of using vibration protection devices for long-length structures [4,5], modeling the contact interaction of a drilling tool with layered or heterogeneous media $[6,7]$, improving the operational properties of a drilling tool through the local application of functionally gradient coatings [8] and providing accuracy, tightness and reliability of threaded connections $[9,10]$ remain relevant. The phenomenon of contact interaction of the elements of the drill string with the borehole wall is an important factor that determines the energy consumption of the drilling process during the rotation of the drill string. Refinement of the models of interaction of the rod surface with an elastic or inelastic medium is necessary to increase the durability of the drill string pipes and ensure high-quality centering of the casing pipes [11, 12].

It is also necessary to ensure the stable operation of wells in the place of their bend $[13,14]$.

The reality of this problem is confirmed by indicators from a stuck drill string during well construction by the UkrBurGas drilling department of the Ukrgasvydobuvannia joint-stock company, the reasons for which are given in Table 1.
Analysis of the production data indicates that the loss of drill string mobility occurred mainly in the intervals of the inclination angle due to its sticking under various conditions, which, according to Table 1, is mainly due to the violation of the integrity of the well walls as a result of crumbling and collapse of rocks and formation of keyseats on the walls of the well. Despite the observance of the operating and technological parameters in the working projects for the construction of these wells, as well as taking into account the recommendations (clause 7.4 of the SOU 09.1-30019775-196:2012 "Wells for oil and gas. Prevention and elimination of accidents during drilling") to prevent keyseating and jamming of the drill string in the keyseats, their trouble-free construction was not ensured, and the problems of sticking the drill string were not solved $[15,16]$.

Literature review. A significant contribution to the development of measures to combat the instability of clay rocks exposed during drilling was made by A.K. Sudakov [17], I. I. Chudyk $[15,16]$.

One of the methods to prevent complications when drilling in clay rocks is to increase the density of the drilling mud, which is recommended by most authors to combat the loss of wellbore integrity and keyseats, which can only change the time of the onset of wellbore complications due to the creation of a larger pressure drop $[18,19]$. To maintain the stability of the borehole walls, it is proposed to carry out a gradual multistage weighting of the drilling mud (clay). Thanks to this, it is possible to delay the onset of complications for a long time, up to running and cementing the casing. This measure is effective when the well section is made up of colloidal, highly swelling clays, and is ineffective in the presence of shales or mudstones, due to the occurrence of a real possibility of micro-fracturing.

It has been experimentally established that a decrease in lateral pressure (from the side of the drilling fluid) leads to brittle destruction of the borehole walls, and its increase leads to deformation and displacement of the rock into the borehole [18].

Also, various methods are often used to increase the mechanical strength of the borehole walls and increase their water tightness and water resistance. These include, for example, [18]:

1) the method of silicatization based on the introduction of liquid glass into the rock once or twice. One-agent silicatization is performed using sodium silicate, to which gelling chemicals are added. Two-agent silicatization is carried out with two solutions: sodium silicate and calcium chloride with the addition of various hardeners (hydrofluorosilicic acid, aluminum sulfate);

2) the method of bituminous grouting of rocks is carried out by injecting liquid bitumen, which is converted into a liq-

Table 1

Industrial data on the reasons for stuck drill string during well construction in the fields of the UkrBurGas Drilling Department [4]

\begin{tabular}{|c|c|c|c|c|c|}
\hline Year & Well No., field & The reason for the sticking & $\begin{array}{c}\text { Stratigraphic characteristics of the } \\
\text { well section }\end{array}$ & $\begin{array}{l}\text { Zenith } \\
\text { angle, } \\
\text { degrees }\end{array}$ & $\begin{array}{l}\text { The depth at which } \\
\text { the sticking occurred, } \\
\text { m }\end{array}$ \\
\hline 2013 & 130-Abazivka & $\begin{array}{l}\text { formation of keyseats, signs } \\
\text { of cave-ins }\end{array}$ & Middle Carboniferous & 18.5 & 3363 \\
\hline 2014 & 11-Sviatohirsk & formation of keyseats & Upper Carboniferous & 8.5 & 3819 \\
\hline 2014 & 508-Medvedivka & $\begin{array}{l}\text { formation of keyseats, signs } \\
\text { of cave-ins }\end{array}$ & $\begin{array}{l}\text { Lower Permian, Upper } \\
\text { Carboniferous }\end{array}$ & 10.0 & 3527 \\
\hline 2015 & 224-Solokhiv & \multirow[t]{2}{*}{ formation of keyseats } & $\begin{array}{l}\text { Lower Carboniferous (Upper Visean } \\
\text { deposits) }\end{array}$ & - & 3690 \\
\hline 2016 & 32-Komyshnia & & (Serpukhovian stage) & - & 5662 \\
\hline 2017 & 183-Melykhivka & $\begin{array}{l}\text { formation of keyseats, signs } \\
\text { of cave-ins }\end{array}$ & Upper Carboniferous & 19.5 & 2858 \\
\hline 2018 & 37- Maksalske & \multirow[t]{2}{*}{ formation of keyseats } & \multirow[t]{2}{*}{ Upper Carboniferous } & - & 2132 \\
\hline 2018 & 108-Zakhidna Solokha & & & - & 3328 \\
\hline 2019 & 200- Melykhivka & \multirow{2}{*}{$\begin{array}{l}\text { formation of keyseats, signs } \\
\text { of cave-ins }\end{array}$} & Upper Carboniferous (araucaria strata) & 2.5 & 3701 \\
\hline 2019 & 1- Zakhidno-Karsnopavlovska & & Middle Carboniferous & 23.9 & 2875 \\
\hline
\end{tabular}


uid state in two ways: by heating or preparing bitumen emulsions (cold bituminous grouting);

3) the method of tarring of rocks is based on polymerization or polycondensation, which are provided by pumping drilling mud of organic high-molecular compounds;

4) the method of electrochemical fastening of clay rocks can be used with their infinitely high resistance of the rock after pumping into the well a special mixture containing binding materials that can quickly tighten and harden when exposed to electric current.

When drilling in low-shale rocks, it is more expedient to use water-based inhibiting drilling fluids, conditionally divided into four classes $[19,20]$ :

1) emulsion drilling fluids saturated with salt, inhibited by calcium chloride, invert emulsions with a controlled aqueous phase, which are recommended for use in soft and plastic clays consisting of $\mathrm{Na}$ - and $\mathrm{Ca}$-montmorillonite, kaolinite, illite, containing 20-40 percent of clay fractions, which actively interact with water;

2) low-mineralized drilling fluids with a low filtration rate, emulsified with oil, for drilling out such clay rocks, which are represented by fractured, hard shales with interlayers of Namontmorillonite and illite, containing 20-30 percent of water-active fractions of clay minerals, with moisture content of $15-25$ percent of and density $2200-2500 \mathrm{~kg} / \mathrm{m}^{3}$;

3) inhibiting drilling fluids (gypsum, calcium chloride), invert emulsions with a controlled water phase or bitumenlime drilling fluids for drilling out brittle and dehydrated shales with low permeability, containing $20-30 \%$ water-active clay minerals, with a natural moisture content of 5-15 percent and density $2200-2500 \mathrm{~kg} / \mathrm{m}^{3}$.

These fluids, from the point of view of practice, are not effective enough or are expensive. Their low efficiency is explained by the fact that all of them are prepared on a water basis, which increases the initial moisture content of clay rocks, which leads to a violation of the integrity of the wellbore.

Taylor D. notes that clay shales, occurring at great depths, in dry form have a strength close to that of rocks. When the rock comes into contact with the aqueous phase of the drilling fluid and is moistened, its strength significantly decreases and the stability of the borehole walls is lost. With an increase in the moisture content of the clays by the drilling mud filtrate, it is not enough to increase the mud density and use water-based inhibiting drilling muds to ensure the stability of the borehole walls. It is necessary to use special drilling fluids, whose filtrate would not moisten clay rocks and would not degrade their initial strength.

Unsolved aspects of the problem. In practice, the stability of the borehole walls is increased with the help of baths which include silicate and silicate-potassium [16, 17] baths. Before lifting the drill string, or during repair work, the calculated volume of silicate or silicate-potassium baths is pumped into the drill pipes and, with the help of drilling mud, it is squeezed into the zone of disturbed rocks and kept for 6-24 hours. Due to the interaction of liquid glass and potassium ions with the borehole walls, the intensity of collapse decreases.

The main disadvantage of silicate and potassium silicate baths is the low period of strengthening the walls of the wells through the dissolution of the previously hardened liquid glass with the filtrate of drilling mud, which penetrates into the walls of the well under the influence of a pressure drop during further deepening of the well.

A more effective way to increase the stability of the borehole walls is the use of a hydrophobic-bituminous bath [16], which consists of diesel fuel and oxidized bitumen. Such a bath increases the strength of rock samples (models) by 110170 percent of the initial value, counteracts the penetration of drilling mud filtrate into the borehole walls and significantly increases the operational life of the bath.

The disadvantage of a hydrophobic- bituminous bath is its high cost, which reduces the likelihood of its use in the practice of drilling wells. After interaction with rocks, the bath is washed out at the wellhead and selected for reuse. If necessary, chemicals are added to the selected bath to improve its properties. In general, liquid baths have adhesive, inhibiting and insulating properties, and therefore increase the stability of the well and prevent its destruction [19]

The use of drilling fluids with high inhibiting properties (polymer-potassium chloride, gypsum-potassium, aluminum- potassium, silicate-potassium, and so on) contributes to the preservation of the borehole walls [20]. However, these fluids fail to completely prevent crumbling and collapse of the borehole walls.

The purpose of the work is to increase the stability of the wellbore during its construction in unstable rocks.

Research objective. Based on the analysis of the information provided, it was found that the sticking of the drill string mainly occurs due to crumbling and collapse of rocks, and they occur at different depths. This can be explained by the tendency of various types of rocks to caving formation. Significant funds are spent to eliminate such complications, and often it is even necessary to change the well design. This situation takes place despite the observance of the current recommendations for the prevention of complications of this kind. Therefore, it can be argued that the measures known to date do not provide troublefree well construction and the problem remains relevant.

It can also be stated that the majority of sticking of the drill string occurs through the formation of keyseats. This can be explained both by the tendency of various types of rocks to form keyseats, and by the imperfect technology of drilling directional wells.

Methods. The most widespread in the practice of well drilling was a fuel-bitumen bath [16]. The peculiarity of such a bath is that the role of the dispersion medium is performed by heating household fuel, and the role of the dispersed phase is played by oxidized bitumen with a softening temperature of at least $100-140{ }^{\circ} \mathrm{C}$.

Heating household fuel is a light brown to black hydrophobic liquid with a pungent odor for domestic use. A feature of household fuel is the increased content of resin fractions, as 90 percent of fuel is obtained in the process of direct distillation of the distillate fraction between diesel fuel and fuel oil at temperatures from 160 to $360{ }^{\circ} \mathrm{C}$. Evaluation of the efficiency of the fuel- bituminous bath in laboratory conditions was carried out on argillo-arenaceous rock samples of four types: 15 percent of clay and 85 percent of sand; 50 percent of clay and 50 percent of sand; 85 percent of clay and 15 percent of sand; 100 percent of clay.

To carry out the experiment, a number of preparatory works are required; in particular, the oxidized bitumen must be heated to the melting point and then dissolved in the household fuel.

Prepared rock samples must first be tested for compressive strength, and it is also necessary to determine their mass. Indestructible argillo-arenaceous rock samples were placed in a fuel-bituminous bath with different concentrations of oxidized bitumen, within 1-9 percent, and kept from 1 to 9 hours. Every 2 hours, rock samples were taken out of the bath and the compressive strength was measured, comparing it with the initial one, and their mass was also determined in order to find out the depth of the bath penetration into the sample.

The duration of the action of the fuel-bitumen bath was estimated as follows. The prepared argillo-arenaceous rock samples were placed in a fuel-bituminous bath for 7 hours, and then the rock samples saturated with a bath were placed in fresh and mineralized water of various concentrations. During 2-3 days, the stability of the rock samples was observed. On the basis of the experiments carried out, it was found that the stability of rock samples increases sharply. A significant increase in stability, in our opinion, is associated with an increased content of resinous fractions in heating household fuel and the adhesion properties of oxidized bitumen.

Results. The research results are shown in Table 2.

Analyzing the results obtained, we should note that, regardless of the permeability of the experimental rock samples, their strength first slightly decreases and then increases. 
The decrease in the strength of the rock samples at the beginning of the experiment, in our opinion, is due to the fact that the adhesive properties of the oxidized bitumen at this time interval are lower than the wedging force arising from the action of heating household fuel.

The decrease in the strength of rock samples depends on their permeability and is 5-18 percent for low-permeability samples, and 20-30 percent for high-permeability samples. With a further increase in the residence time of the rock samples in a fuel-bituminous bath, their strength increases, which, in our opinion, is associated with an increase in adhesion forces in a rock sample at a constant value of the wedging force.

The strength of argillo-arenaceous rock samples depends on the concentration of oxidized bitumen in the fuel-bituminous bath, the residence time of rock samples in the bath and their permeability.

With an increase in the concentration of oxidized bitumen in the bath with the same residence time of the rock samples in it and the rock permeability, an increase in the strength of the rock sample is first observed, which reaches a maximum value, and then stabilizes. This pattern is observed for all types of rock samples, regardless of their permeability. The existence of the maximum concentration of oxidized bitumen in the fuelbituminous bath can be associated with the formation of a thin low-permeability film on the surface of the rock samples, which forms a barrier to the penetration of the adhesive into the rock. Therefore, despite the increase in the concentration of the adhesive, the strength of the rock samples is stabilized. The maximum concentration of oxidized bitumen in heating household fuel is 5-9 percent for all types of samples.

With an increase in the duration of stay of rock samples in a fuel-bituminous bath, their strength increases, which is associated with an increase in the adhesion properties of the bath.

The greatest increase in the strength of the samples is observed after staying in the fuel-bituminous bath for 78 hours [17].

The fuel-bituminous bath, in contrast to the silicate-potassium bath, increases the strength of all types of rock samples, regardless of their permeability.

Thus, as a result of the experiments, it was found that the greatest increase in strength is observed for high-permeability rock samples -410 percent; somewhat smaller - for mediumpermeability rocks -150 percent and the smallest $-125-$ 130 percent for low-permeability rocks.

It should also be said that the stability of rock samples saturated with fuel-bituminous baths reaches 50 days in filtrates of potassium chloride and salt-saturated solutions.

Thus, according to the results of the laboratory studies, it is recommended to introduce into the practice of drilling a fuel-bituminous bath of the following composition: heating fuel $-91-95$ percent, oxidized bitumen $-5-9$ percent. The holding time of the well bath in front of the horizons prone to

Table 2

Results of experimental studies on the dynamics of destruction of samples of clay rocks, depending on the time spent in a fuel-bituminous bath

\begin{tabular}{|c|c|c|c|c|}
\hline \multirow{3}{*}{$\begin{array}{l}\text { The holding time of the } \\
\text { samples in the bath, h }\end{array}$} & \multicolumn{4}{|c|}{ Sample type } \\
\hline & $\begin{array}{l}85 \text { percent of sand }+15 \text { percent } \\
\text { of clay }\end{array}$ & $\begin{array}{l}50 \text { percent of sand }+50 \text { percent } \\
\text { of clay }\end{array}$ & $\begin{array}{l}15 \text { percent of sand }+85 \text { percent } \\
\text { of clay }\end{array}$ & $\begin{array}{l}100 \text { percent } \\
\text { of clay }\end{array}$ \\
\hline & \multicolumn{4}{|c|}{ Destructive compressive stress, $\mathrm{MPa}$} \\
\hline \multicolumn{5}{|c|}{99 percent of heating household fuel and 1 percent of oxidized bitumen } \\
\hline 0 & 0.125 & 0.726 & 0.777 & 0.842 \\
\hline 2 & 0.092 & 0.514 & 0.577 & 0.697 \\
\hline 4 & 0.142 & 0.436 & 0.535 & 0.581 \\
\hline 6 & 0.159 & 0.399 & 0.577 & 0.631 \\
\hline 8 & 0.183 & 0.522 & 0.668 & 0.683 \\
\hline 9 & 0.188 & 0.606 & 0.747 & 0.791 \\
\hline \multicolumn{5}{|c|}{97 percent of heating household fuel and 3 percent of oxidized bitumen } \\
\hline 0 & 0.125 & 0.726 & 0.777 & 0.842 \\
\hline 2 & 0.085 & 0.387 & 0.733 & 0.738 \\
\hline 4 & 0.130 & 0.527 & 0.763 & 0.815 \\
\hline 6 & 0.174 & 0.564 & 0.829 & 0.838 \\
\hline 8 & 0.189 & 0.702 & 0.837 & 0.862 \\
\hline 9 & 0.205 & 0.73 & 0.850 & 0.886 \\
\hline \multicolumn{5}{|c|}{95 percent of heating household fuel and 5 percent of oxidized bitumen } \\
\hline 0 & 0.125 & 0.726 & 0.777 & 0.842 \\
\hline 2 & 0.243 & 0.479 & 0.791 & 0.75 \\
\hline 4 & 0.359 & 0.548 & 0.899 & 0.85 \\
\hline 6 & 0.435 & 0.636 & 0.976 & 0.905 \\
\hline 8 & 0.469 & 0.728 & 0.993 & 0.975 \\
\hline 9 & 0.515 & 1.089 & 1.000 & 1.05 \\
\hline \multicolumn{5}{|c|}{91 percent of heating household fuel and 9 percent of oxidized bitumen } \\
\hline 0 & 0.125 & \begin{tabular}{|c|c|}
0.726 \\
\end{tabular} & 0.777 & 0.842 \\
\hline 2 & 0.277 & 0.489 & 0.759 & 0.792 \\
\hline 4 & 0.384 & 0.594 & 0.874 & 0.892 \\
\hline 6 & 0.455 & 0.703 & 0.947 & 0.956 \\
\hline 8 & 0.479 & 0.734 & 0.958 & 0.981 \\
\hline 9 & 0.500 & 0.796 & 0.984 & 1.031 \\
\hline
\end{tabular}


collapses is $7-8$ hours. The cost of a fuel-bituminous bath is three times less than that of a hydrophobic-bituminous bath. Therefore, taking into account the effectiveness in various rocks, the relatively low cost and a significant period of operation, the fuel-bituminous bath is the most effective in the fight against crumbling and collapses of the walls of wells.

In the case when the intensity of the collapse of the walls of the well cannot be prevented with the help of a fuel-bituminous bath, then we recommend blocking the collapse zone with a casing string (Patent of Ukraine for utility model No. 139414). In order for the casing string to be successfully lowered into the well and then pressed against its walls, in order to cover the entire surface of the caving zone, the casing string is corrugated, that is, four depressions are made on the pipe surface (Fig. 1). In the places of the depressions in the upper and lower parts, metal conical rods are installed. To improve the attachment of the casing to the borehole walls, reverse teeth are made on the reverse side of the metal conical rods, which prevent the rod from coming out of the rock.

The procedure for running corrugated casing with conical rods is as follows. First, the casing pipes are corrugated, as shown in Fig. 1. The left adapter is installed in the upper part of the pipe, and the pipes are connected to each other with special collars. A landing seat is installed at the bottom of the device. In the upper and lower parts, conical rods with teeth are fixed.

The assembled device, as shown in Fig. 1, is lowered into the well. Before the descent, the interval, where there is an intensive collapse of rocks, is intensively worked out. Opposite the horizon, which is collapsing, the descent is stopped. A metal ball is lowered into a pipe string. The pumps are started, their productivity is gradually increased while increasing the pressure inside the column. At the moment when the metal rods with reverse teeth enter the rock, and the metal shell squeezes tightly against the walls of the well, the pumps are stopped. The casing is securely attached to the borehole wall. By turning to the right, the drill string is unscrewed and a special expander is lowered into the device, which aligns the collars. Alignment of collars is carried out at low rpm and light load.

In the case when the rocks that are prone to collapse of the borehole walls are of great thickness, we recommend an improved device. The recommended device differs from the above one in that there are additional metal rods in the pipe corrugation, which have check valves through which the adhesive is pumped into the rock mass (Patent of Ukraine for utility model No. 140141). The design of the device shown in Fig. 2 is assembled and lowered into the well. A metal ball is lowered into the pipe string. Following it, an adhesive is

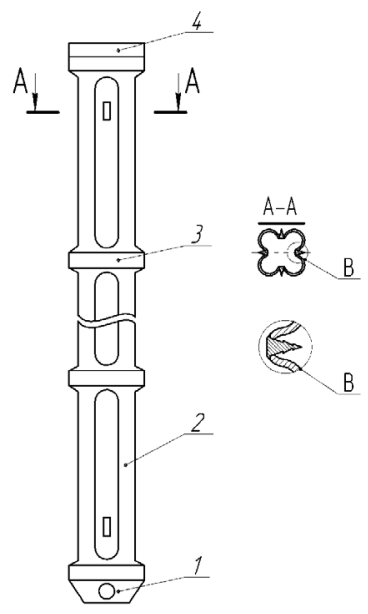

Fig. 1. A device for covering the walls of the well, which are intensively collapsing:

1 - landing seat; 2 - corrugated pipe; 3 - collars; 4 - top adapter with left-hand thread; 5 - metal conical rods with reverse teeth launched, whose volume is determined experimentally according to formula

$$
V_{a}=\frac{\pi}{4} \cdot\left(K_{c} \cdot D_{b}^{2}-D_{d}^{2}\right) \cdot l,
$$

where $D_{b}$ is the diameter of the bit opposite the interval of the installed device; $K_{c}$ is the caving coefficient; $D_{d}$ is the outer diameter of the device; $l$ is the length of the intensively collapsing interval, $\mathrm{m}$.

The pumps are started and the pressure is gradually raised, which is determined by formula. At the moment when the pressure $\left(P_{\text {int.cr. }}\right)$ reaches that value which is necessary to align the corrugation of the device, the pumps are stopped

$$
P_{\text {int.cr. }}=P_{w h}+P_{\text {hydr. }},
$$

where $P_{w h}$ is the estimated pressure at the wellhead, $\mathrm{Pa} ; P_{h i d r}$ is the hydrostatic pressure, $\mathrm{Pa}$.

The maximum internal pressure should be no more than the critical internal excess pressure formula

$k$ is the stability coefficient equal to formula

$$
k=\frac{\delta}{D_{d}},
$$

where $\delta$ is the wall thickness, $\mathrm{mm}$.

The top and bottom rods will enter the formation and securely attach the string to the borehole wall due to the reverse teeth of the rods. To open the check valves, internal pressure is additionally raised on $\Delta P=0.1 \cdot k \cdot \sigma_{Y}$ and the adhesive enters the rock mass, which is collapsing. After pressing the pump is stopped, the check valve is closed. The well is left at rest until the adhesive hardens. After that, as in the previous case, the drill string is turned to the right, aligning the collars. The use of an adhesive increases the contact area of the metal shell with the rock that collapses and increases the stability of the borehole walls.

Conclusions. As a result of the performed work, the expediency of using fuel-bituminous bath with oxidized bitumen content of 5-9 percent for strengthening the walls of wells in deposits of clay rocks, including clay shales, with a duration of its stay in the well for 7-8 hours has been established and substantiated.

It is recommended to use corrugated casing pipes to cover the sections of the wellbore where there is intensive crumbling and collapse of rocks.

In further studies, it is planned to develop methods for preventing the occurrence of the keyseats on the walls of a directional well on the basis of complex use of results of analyti-

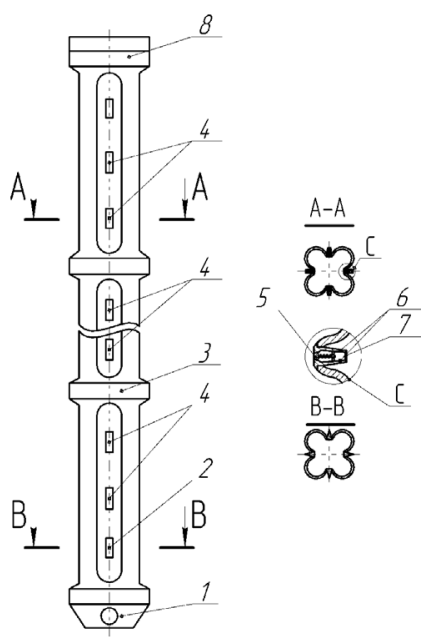

Fig. 2. An improved device for covering the walls of the well, which are intensively collapsing:

1 - landing seat; 2 - metal rods with reverse teeth; 3 - collars; 4 - intermediate metal rods; 5 - check valve; 6 - openings; 7 plug; 8 - adapter with left-hand thread 
cal modeling of practical experiment by express assessment of stability of rocks in the near-wellbore zone under conditions of its destruction.

\section{References.}

1. Ivasiv, V., Yurych, A., Zabolotnyi, S., Yurych, L., Bui, V., \& Ivasiv, O. (2020). Determining the influence of the condition of rockdestroying tools on the rock cutting force. Eastern-European Journal of Enterprise Technologies, 1(1-103), 15-20. https://doi. org/10.15587/1729-4061.2020.195355.

2. Yurych, L. R., Ivasiv, V. M., Rachkevych, R.V., Yurych, A. R., \& Kozlov, A. A. (2016). The use of elastic elements for wellbore trajectory Management. Neftyanoe Khozyaystvo - Oil Industry, (2), 36-37. 3. Vytiaz, O.Yu., Hrabovskyi, R.S., Tyrlych, V.V., \& Artym, V.I. (2018). Assessment of the impact of dynamic loads on the conditions of destruction of pipes of drill strings during round tripping operations. Scientific bulletin of IFNTUOG, 1(44), 25-34.

4. Dutkiewicz, M., Gołębiowska, I., Shatskyi, I., Shopa, V., \& Velychkovych, A. (2018). Some aspects of design and application of inertial dampers. MATEC Web of Conferences, 178, 06010. https://doi. org/10.1051/matecconf/201817806010.

5. Velychkovych, A., Petryk, I., \& Ropyak, L. (2020). Analytical study of operational properties of a plate shock absorber of a sucker-rod string. Shock and Vibration, 2020, article ID 3292713. https://doi. org/10.1155/2020/3292713

6. Ropyak, L. Ya., Pryhorovska, T. O., \& Levchuk, K. H. (2020). Analysis of Materials and Modern Technologies for PDC Drill Bit Manufacturing. Progress in Physics of Metals, 21(2), 274-301. https:// doi.org/10.15407/ufm.21.02.274

7. Grydzhuk, J., Chudyk, I., Velychkovych, A., \& Andrusyak, A. (2019). Analytical estimation of inertial properties of the curved rotating section in a drill string. Eastern-European Journal of Enterprise Technologies, 1(7-97), 6-14. https://doi.org/10.15587/1729-4061.2019.154827.

8. Shatskyi, I. P., Perepichka, V.V., \& Ropyak, L.Y. (2020). On the influence of facing on strength of solids with surface defects. Metallofizika i Noveishie Tekhnologii, 42(1), 69-76. https://doi.org/10.15407/ mfint.42.01.0069.

9. Pryhorovska, T., \& Ropyak, L. (2019). Machining Error Influnce on Stress State of Conical Thread Joint Details. Proceedings of the International Conference on Advanced Optoelectronics and Lasers (CAOL), 9019544,493-497.https://doi.org/10.1109/CAOL46282.2019.9019544. 10. Shatskyi, I., Ropyak, L., \& Velychkovych, A. (2020). Model of contact interaction in threaded joint equipped with spring-loaded collet. Engineering Solid Mechanics, 8(4), 301-312. https://doi. org/10.5267/i.esm.2020.4.002

11. Vytvytskyi, I. I., Seniushkovych, M.V., \& Shatskyi, I. P. (2017). Calculation of distance between elastic-rigid centralizers of casing. Naukovyi Visnyk Natsionalnoho Hirnychoho Universytetu, (5), 28-35.

12. Shatskyi, I., Velychkovych, A., Vytvytskyi, I., \& Seniushkovych, M. (2019). Analytical models of contact interaction of casing centralizers with well wall. Engineering Solid Mechanics, 7(4), 355366. https://doi.org/10.5267/i.esm.2019.6.002.

13. Petlovanyi, M., Lozynskyi, V., Saik, P., \& Sai, K. (2019). Predicting the producing well stability in the place of its curving at the underground coal seams gasification. E3S Web of Conferences, 123, 01019. https://doi.org/10.1051/e3sconf/201912301019.

14. Vytyaz, O.Y., Hrabovskyy, R. S., Artym, V.I., \& Tyrlych, V.V. (2020). Effect of geometry of internal crack-like defects on assessing trouble-free operation of long-term operated pipes of drill string. Metallofizika i Noveishie Tekhnologii, 42(12), 1715-1527. https://doi. org/10.15407/mfint.42.12.1715.

15. Orynchak, M.I., Riznychuk, A.I., Orynchak, M.M., \& Beizyk, O. S. (2010). Fuel-bituminous bath. Exploration and development of oil and gas fields, 3(40), 90-95.

16. Chudyk, I. I., Femiak, Ya. M., Riznychuk, A.I., Vasko, I. S., \& Yurych, L. R. (2019). Experimental studies of mechanical properties of rocks in thermobaric conditions. Exploration and development of oil and gas fields, 3(72), 32-41.

17. Sudakov, A., Chudyk, I., Sudakova, D., \& Dziubyk, L. (2019). Innovative technology for insulating the borehole absorbing horizons with thermoplastic materials. E3S Web of Conferences, 123, 01033. https://doi.org/10.1051/e3sconf/201912301033.

18. Ashena, R., Elmgerbi, A., Rasouli, V., Ghalambor, A., Rabiei, M., \& Bahrami, A. (2020). Severe wellbore instability in a complex lithol- ogy formation necessitating casing while drilling and continuous circulation system. Journal of Petroleum Exploration and Production Technology, 10, 1511-1532. https://doi.org/10.1007/s13202-020-00834-3. 19. Ayoub Darvishpour, Masoud Cheraghi Seifabad, David Anthony Wood, \& Hamzeh Ghorbani (2019). Wellbore stability analysis to determine the safe mud weight window for sandstone layers. Petroleum Exploration and Development, 46(5), 1031-1038. https://doi. org/10.1016/S1876-3804(19)60260-0.

20. Samit Mondal, \& Rima Chatterjee (2019). Quantitative risk assessment for Optimum Mud weight window design: A case study. Journal of Petroleum Science and Engineering, 176, 800-810. https:// doi.org/10.1016/j.petrol.2019.01.101.

\section{Нові способи боротьби з осипанням та обвалами стінок свердловин}

\section{I. Чудик', Я. М. Фем'як', М. I. Оринчак ${ }^{1}$, A. К. Судаков ${ }^{2}$, А. І. Різничук ${ }^{1}$}

1 - Івано-Франківський національний технічний університет нафти і газу, м. Івано-Франківськ, Україна, е-таil: chudoman@ukr.net

2 - Національний технічний університет «Дніпровська політехніка», м. Дніпро, Україна

Мета. Полягає в підвищенні стійкості стовбура свердловин при їх спорудженні в нестійких гірських породах.

Методика. Для вирішення поставлених завдань у роботі використовується комплексний підхід, що включає критичний аналіз і узагальнення науково-технічних досягнень у поєднанні з теоретичними та експериментальними дослідженнями.

Результати. Проаналізовані фактори, що впливають на стійкість стінок свердловини в умовах, схильних до осипань і обвалювань гірської породи. Встановлена і обгрунтована доцільність використання ванн для зміцнення стінок свердловин у відкладах глинистих гірських порід, у тому числі й глинистих сланців. Запропонована рецептура паливно-бітумної ванни, встановлення якої у свердловині впродовж 7-8 годин дає змогу підвищити початкову міцність гірських порід на стиснення, що забезпечить цілісність стінок стовбура. Для перекриття ділянок стовбура свердловини, де інтенсивні осипання та обвалювання гірської породи, рекомендується застосовувати гофровані обсадні труби.

Наукова новизна. Уперше встановлені основні чинники виникнення ускладнення й розроблено метод запобігання руйнуванню стінок скерованих свердловин, складених гірськими породами, схильними до втрати стійкості під дією навантажень бурильною колоною.

Практична значимість. Для запобігання руйнуванню стінок скерованих свердловин, складених гірськими породами, схильними до втрати стійкості, авторами запропоноване облаштування в інтервалі ускладнення паливнобітумних ванн. У випадку, коли обвалюванню стінок свердловини за допомогою паливно-бітумної ванни не вдається запобігти, запропоновано перекривати зону обвалювання обсадними колонами з використанням удосконалених гофрованих обсадних труб, із закачуванням клеючої речовини до масиву гірської породи пристовбурової зони свердловини. Застосування клеючої речовини збільшує площу контакту поверхні обсадної колони з нестійкою породою, підвищуючи стійкість стінок свердловини.

Ключові слова: буріння, бурові технологічні рідини, каверна, осипання, обвалювання, гофрована обсадна труба

Recommended for publication by D. Yu. Petryna, Doctor of Technical Sciences. The manuscript was submitted 16.02.21. 